\title{
Architectural history through Archaeological research in the historical and cultural conservation area of Absheron
}

\begin{abstract}
The first archaeological research started in" Qala Baku" and "Abshiroun" in 1920 and 1941, respectively. 13 historical traces related to the stone era, 6 residential places related to the Bronze era, and architectural remains related to the mediate era were discovered in the historical and artistic protected area of the Qubostan. During the excavations of the historical and architectural old city, some rich historical traces were revealed. This showed that Baku city was a residential place and there was a rich system of business and different industries in the mediate era. The first findings of the historical and protected area of the Qala were found in the southern part of the village including some remains of the different stone buildings and pieces of clay on which different figures were painted in this place. This indicates the historical enrichment of this residential place. Also, some findings related to the Bronze era were discovered in this place. Moreover, some historical traces related to the first period of $\mathrm{BC}$ and Bronze era were found in Nardaran village. In the area which is known as QalaGah, the human settlement was found inside the caves. Much information was revealed aboutthe architecture and history in a fire worshiping temple in the Sourkhan village. This fire temple is related to the 18th century. Excavations showed that this temple was built on an older fire temple.
\end{abstract}

Volume 3 Issue 6 - 2018

\author{
Rahiba Aliyeva \\ Assistant-professor, Department of architecture,Azerbaijan
}

Correspondence: Rahiba Aliyeva, Assistant-professor, Department of architecture, Azerbaijan, Email rahibe_eliyava@mail.ru

Received: December 03, 2018 | Published: December 04, 2018

\section{Introduction}

Two references include written resources and cultural-material resources are used for Archaeological and historical research. The latter resources are much more accurate and are considered as the historical invariable elements. These archaeological elements are intermediate between humans of the pre-written era. The beginning of human habitation on the peninsula of Abshiroun is one of the questions that have attracted scientists' attention in the recent decades. The answer to this question is obtained by the research through Historic remains and traces of ancestors. Remained heritage in this peninsula is rich. First time, the archaeological research was launched in 1941 in Abshiroun and in 1920 in the Baku castle. Some scientists such as OS Ismizade, FE Ibrahimov, IM Safarzade, EA Paxomov investigated the old city and IM Safarzadeh, QM Aslanov, I Aliyev looked into residential settlements in the Abshiroun. Discovery of the cultural material related to the early Iron era by IM Safarzade has been considered as a great finding for Abshiroun. The next step of research was performed by $\mathrm{M}$ Aslanovsin the $60^{\text {th }}$ decade of the $20^{\text {th }}$ century. The results of the research change the views about Ancient civilization traces and provide the review of the research even about Civilization in the third millennium BC. In 1985, archaeologist started the new research inAbshiroun area. In the research on the extracted historical material performed by I Aliyev in the East of the Peninsula, in the shoreline, it was demonstrated that Abshiroun was a residential area in the ancient times.

From the end of 2002 so far, no new finding have been obtained about living status in the Abshiroun. Residential settlements of primitive human related to upper Paleolithic period in the 2000 years ago was discovered. Then, the human lived there for thousands of years before what previous research showed. It can be said that due to the high population, human settled in this placethousand years ago.
The Abshiroun residential center is located in the new rural districts in the Southern Sourkhani. There is the possibility of the discovery of these residential settlements in other parts of the Abshiroun. ${ }^{1}$ The archeology research shows that there were religious and historical monuments in the Abshiroun peninsula in the third and second Millennium BC. Traditional development of the Especial Architecture in Abshiroun was continued until the second millennium BC. In this era, the stages of cultural and social development took place in the Caucasus peninsula and then the archeological element set was similar to elements of the Southern Caucasus. All these discoveries were identified by looking into the disposable elements of the third and second millennium $\mathrm{BC}$ which were similar to Caucasus and Middle East civilization. ${ }^{1}$

Historical- artistic protected area of the Qobustan: the archeological research in the Qobustan protected area was launched somehow between 1939-1940 but was delayed because of the World War II and again restarted in 1947. In this place, many monuments and historical traces of the Stone Age were found. There were ancient residential places and buried hills (Kourgan) in this place. More than 20 residential places and more than 30 Kourgan and 6000 Pictures painted on the stone were discovered in this place. Mesolithe was found In more than 5 of the shelters (such as Zaga, Kanize, Firouz, and 4 Shelters under rock). Neolith was found in 4 of the shelters (Zaga, Kanize, hunting, deer). Bronze was found in 7 of the shelters (Zaga, Kanize, cows, Firouz, big stone, circle, and 5 under rock shelters). One of the shelters was related to the ancient age (Zaga). 5 of the shelters were related to the middle age (Kanize, 5 under rock shelters, Firouz, deer, written hill).

As a Result of the archeological excavations in the Qobustan related to the Bronze era, the work tools, household appliances, crockery, animal bones, a necklace made of animal bones, and 11 human graves were found. In addition to other ancient tools, a figurine 
of a woman's body was also found in the Kanize .Findings show that the environmental conditions were appropriate for human life in the Mesolith and Neolith era. Moreover, these findings prove the existence of fishing and hunting in the Mesolith and Neolith era and agriculture and animal husbandry in the Bronze era. ${ }^{1}$ The first research in the Qubostan was performed by IM Safarzade in the years 19351940. In this research, 3500 pictures painted on the stone that are related to the early human were represented. The ancient people of the Qobustan mainly lived outdoors because of the appropriate situation and climate of this place. To protect from the outside dangers, they lived in the Caves and rock shelters such as Buyak Tash and Kutchuck Tash mountains in the Southeast. The archeologists called these life places "Cardaq Zaga" and the other kind was called" Firouz". In both shelters, the West side of the roof consists of big rock stone that was covered by the soil. These kinds of shelters are placed in the South of the Buyuk Tash Mountain and known as Guzelle Yyddy cave. There is a great shelter between hunter Zaga and main Zaga. In the honor of its discoverer, this cave was called JafarZade. Ginger Daghi and Tazili hills were already the same, but laterthey were washed away by the soft soil and running water and placed in the new situations., 13 residential areas of the stone era, 6 residential places of the Bronze era, and one building related to the middle era also appeared. In the residential place related to the Mesolith era of Qubostan (main Zaga, Kanize, Firouz, cows, deer, between rocks) the bottom rock shelters appeared. Among the big pieces of the rock, the cave- shelter was used for housing for a long time and had the significant role before architectural structures. Carving by the stone was observed at the Kanize shelter. In some cases, the thickness of the shelter was more than 1 meter. During the investigation, much stone architecture and animal bones and the remains of stoves were observed. On the wall and rocky layers of the shelters, the stone decoration and on the some rocks, the animal and human figures were observed. ${ }^{4}$ In Qubostan, as an ancient civilization, near the Buyuk Tash cave, the tablet with Latin letters was found which was related to the Roman Empire in the first millennium AD. Stone pictures in Qubostanare different from each other in terms of written technique, size and structure. This also reflects the different petrography in various periods. The historical traces in Qubostan such as initial living place of Azerbaijan's people, traditions, old civilization and artistic origins, early human architecture and lifestyle and whatever they used to protect themselves against environmental effects, are important resources (Figure 1) (Figure 2).

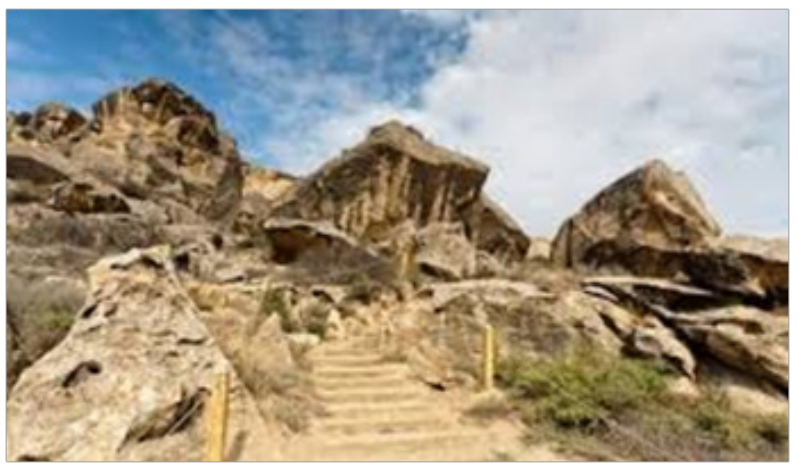

Figure I Qubustan prehistoric Archeological site.

The historical- artistic protected area of the old city: for the first time, the archaeological research started in the Baku castle in 1920. The practical research was continued in the old city of Baku by OS Esmizade, FE Ibrahimov, I M. Safarzade, and A Paxomov and several archaeological excavations were implemented. During these excavations, a rich civilization was discovered. It was demonstrated that Baku city was a residential place. It was shown that there were an extensive business systemand different industries as well as urban setting of different periods. In order to study the history and civilization of the old city, important archaeological research and excavations were performed by the historical museum of Azerbaijan in the years 1924-1925 and 1945-1946. During excavation in the Shirvan Shah's palace grounds, near the tomb, significant historical materials were discovered. Near the tomb, the remaining traces of a mosque, consisting of several parts near the tomb's wall as a network layout was revealed.In that place, the remains of the walls of buildings were extracted. During excavation, copper coins minted by the Seljuk and Shirvan Shahgovernment were found. This shows that these buildings dated back to the Eleventh and twelfth era and the Darvish's tomb in the Shirvan Shah's palace had been build before that time. ${ }^{4}$

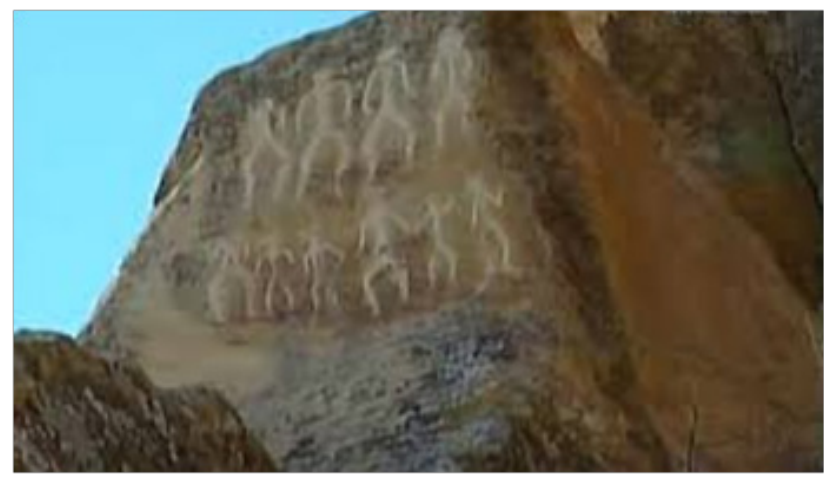

Figure 2 Qubustan prehistoric Archeological site.

Archaeological excavation around the Qiz Qala castle is very important. In the sixties of the $20^{\text {th }}$ century, a structural work around the Ghale Dokhtar castle called Bazar Yeri was extracted with the regular vaults. In 1964, O EsmaeilZade and Q Jedi reported that there were two small doors in the Eastern and Western walls of this building. These two doors which opened to the East and West represented the symbol of worshipping the sun and indicated that this place was a Zoroasterian temple. Short doors make the bow on arrival. During excavations, more than 50 graves were sound and the direction of the graves was toward Qibla that showed the Islamic burial. Some of the graves were placed on each other. This showed that the Cemetery was related to the several thousand years ago. Also, some rectangular channels were found that were 50 Centimeters wide and 60-70 Centimeters long and made of the carved stones. In some found graves, the historical traces related to the $14^{\text {th }}$ and $15^{\text {th }}$ century was observed. Also, a stone pillar with a three step balcony on each side as an eight-corner shape was found in the depth of 4.5 meters. In the upper section of stone, a hole was drilled for firewood storage. Definitely, these historical traces are related to the fire- worshipping period. Moreover, some Shirvan Shahi's coins related to the $12^{\text {th }}$ and $14^{\text {th }}$ century were found in the depth of 2.5 meters. In the mediateera, these kinds of burial were performed in the monasteries that were placed in the building sets. Research shows that this monastery, which was near the GhaleDokhtar castle, is related to the Sheykh Taher. ${ }^{5}$

In the present, the architectural protection has been performed and the archaeological traces have been identified by supervising F Ebrahimov and the results of excavations have been studied. The results show that there were vault and roof of the ceiling in front of 
the Christian temples near the Qiz Qala. Today, these monuments are protected. Inside the castle walls, some expensive materials and the palace are found- like buildings and civilization traces, in accordance with the spirit of the old city. These historical traces are composed of Pottery and Ceramic productions, rock mixture, Copper and Silver coins, and the building's ceramic. These materials demonstrate that in the mediate era, the production of goods and crockeries were highly developed and completed. The technology of producing and preparing of these crockeries depends on its development. Archaeological excavations Performed in the old city revealed a set of dishes without glaze and color. Some of these dishes include kitchen dishes, storage containers of food, food transport containers, Construction Ceramics, pitcher of water, and toys for children. Among the objects found from $12^{\text {th }}$ and $13^{\text {th }}$ century, simple unglazed pottery depicted by compression can be seen. In the historical dishes of Baku castle, different glazed and decorated ceramics were observed. Among the dishes related to the $7^{\text {th }}, 9^{\text {th }}$, and $13^{\text {th }}$ centuries, there were the Saucers, bowls, and plates. Also, the transparent painting, decorating transparent and manganese cover, enamels and glazes, colorful dish such as yellow, green and brown dishes. The pictures of the animals and plants, fishes, birds and human were depicted on the plates and bowls. ${ }^{6}$

Ceramic had an important role in the water system of the Azerbaijan and Baku in the mediate era. The archaeological findings demonstrate that the Aqueduct system withceramic- clay channel for water channel was used in the water system of the Baku city. It is necessary to mention that based on the Shirvan- Abshiroun architecture, the Building Materials were not brick, but local limestone. Construction ceramics were made of the regular and shiny tiles. Different shapes of monochrome tile such as Persian blue, cyan, and green were found that were related to the $12^{\text {th }}$ and $13^{\text {th }}$ century. Big clay tiles in different sizes with blue glazed related to the $14^{\text {th }}-17^{\text {th }}$ century was also found. Glass materials were found in the North wall of the castle. In the downtown, many of glassy dishes and jug with narrow wall, Vase, bowl or container of medicine and a small perfume were obtained. Moreover, many colorful,glassy,and twisted dishes, and glassy beads were found.

Among the obtained objects in the city, there were many Copper and silver coinages. These coinages were individually or as a treasure. These coinages are very important historically. It is interesting that many of the coins were minted in Baku. Relayed on these findings, Researchers conclude that there was the mint in the Baku in the mediate era. Among coins found in Baku, some coins were minted in Shamakhi, Tabriz, Panha Abad, Ganje, Darband, Shirvan, Mahmoud Abad, Irvan, Kashan, Bokhara, Zanjan, Soltaniye and coins of the Horde were observed. This shows that Baku was a Commercial and civilized city in the mediate era. ${ }^{6}$ There were ovens found that were used for supplying the food of people of Baku in the mediate era. Bread baking had the ancient history in the Azerbaijan. The archaeological excavations show that in Azerbaijan and Caucasus, the oven was used for baking bread from the Enolith era and completed later. ${ }^{6}$ Along the Northen wall, almost all the ovens were made of especial crushed yellow clay mixed with sand as layers of 2.5-3.5 Centimeters .Their diameters were 45-50 centimeters. Among these ovens, there were some big ovens. For example, there is an oven with $1.5 \mathrm{M}$ diameters related to the $14^{\text {th }}$ and $15^{\text {th }}$ centuries in the Shirvan Shahi palace. This is the first oven that was found in such a size. In some places, more than 5-6 ovens were found related to different centuries.

In the upper part of the city that is related to the $14^{\text {th }}-17^{\text {th }}$ centuries, the ovens with different sizes were found which suggests that this section of the city might be the baker's alley. Also, there were ovens, braziers, and waste disposal wells in the yards. For the first time, during the excavations, they found a large warehouse in the West south part of the city. ${ }^{6}$ Remained historical traces in the downtown related to $9^{\text {th }}$ and $11^{\text {th }}$ centuries, which reflect the ancient civilization of the Baku city, are much more attractive. The information about this era is little. Found architectures in this part show that the building's foundation was placed on the stone. Butvery few construction remains are left. The walls of the upper part of the city are thicker and in some cases the wall thickness reaches to 1 meter. It is found In the research that the small rooms were square and made of the carved stone. One part of the architecture of the downtown was the well digging in the different dimensions. These wells were used to store the cereals and other productions. ${ }^{2}$ During the excavating and creating a recreation area, these kinds of wells were found in the entrance door of the castle in 2013. Wells were close to each other and this shows that a large family lived in this place. Because of protecting the architecture and historical traces of the old city, archaeological excavations are hardly implemented. The presidential decree of Ilham Aliyev stated that "archaeological excavations can be performed just in the areas in which there was any historical architecture", shows the importance of the ancient traces. Therefore, there are many problems for excavations in this area.

In the years 2010-2012, during the excavations in the protected area of the Jewelers area, a painter discovered underground passages, 2 graves, and a living room with roof and vault. Based on the findings in this protected area, there were gardens with traces in the upper part of the city. Careful analysis of the protected areas of the old city and programmed excavations around the castle are necessary to open up the multi- layer civilization of this city. We hope that this research brings up some serious attention to highlight the importance of Baku's archeology (Figure 3)(Figure 4). Historical protected area of the Qala: performed excavations in this area convince us to reconsider the history of the human life in this area. For some long years, it seemed that Abshiroun was created in the mediate era, but in the recent years, some excavations have shown that this castle was created in the Bronze era. First discoveries were obtained in the southern part of the village. Stone architectural constructions, Pottery pieces, and residential places were found in this place. At the same time, during the investigation on the bathroom remained from 14th and 15 th centuries, some knives made of the flint and tablets were found near the Qale salt lake. At the end of 2007, the archaeological excavations started around the southern part of the castle (Qala) and some historical traces were found related to the Bronze era.

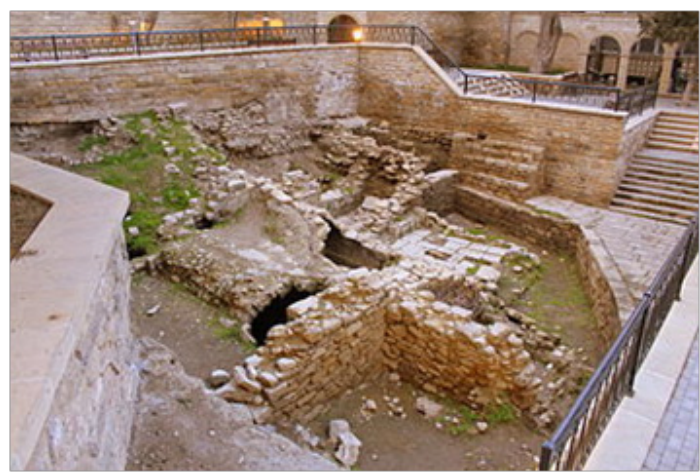

Figure 3 Historical Church in Icharishahar. 


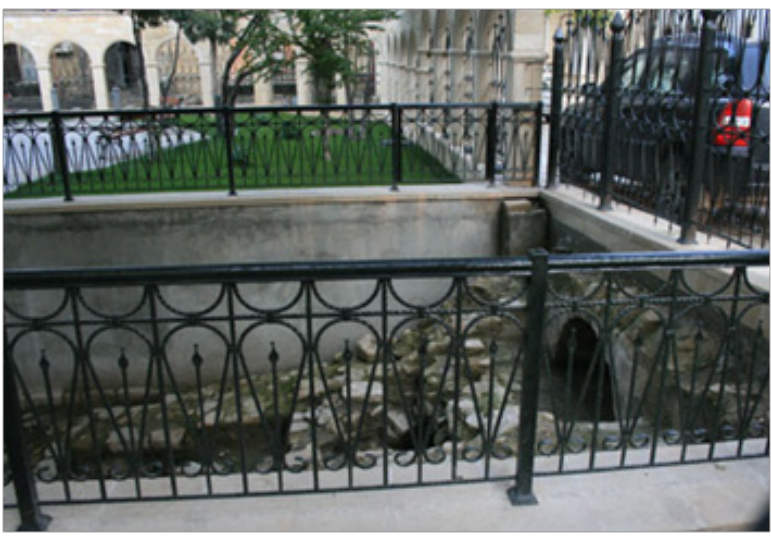

Figure 4 Archeological parck in in Icharishahar

During the excavations, some historical traces related to the 13th-18th centuries were found including some glazed pottery that indicates the civilization and business development in the 10th-14th centuries. Some dishes in the downtown had the builder's seal. This demonstrates the existence of the Pottery workshops in this place. Also, remains of Pottery ovens were found in this place. Absyden tablets related to the second or third millennium BC, Remains from the Bronze Age andmany flint knives were found in this place. These findings show the background ofhistorical villages of the Abshiroun, such as Mardakan, Buzurna, Sourkhani, Amirjan, and Zigh is from ancient centuries (Figure 5)(Figure 6). ${ }^{8}$
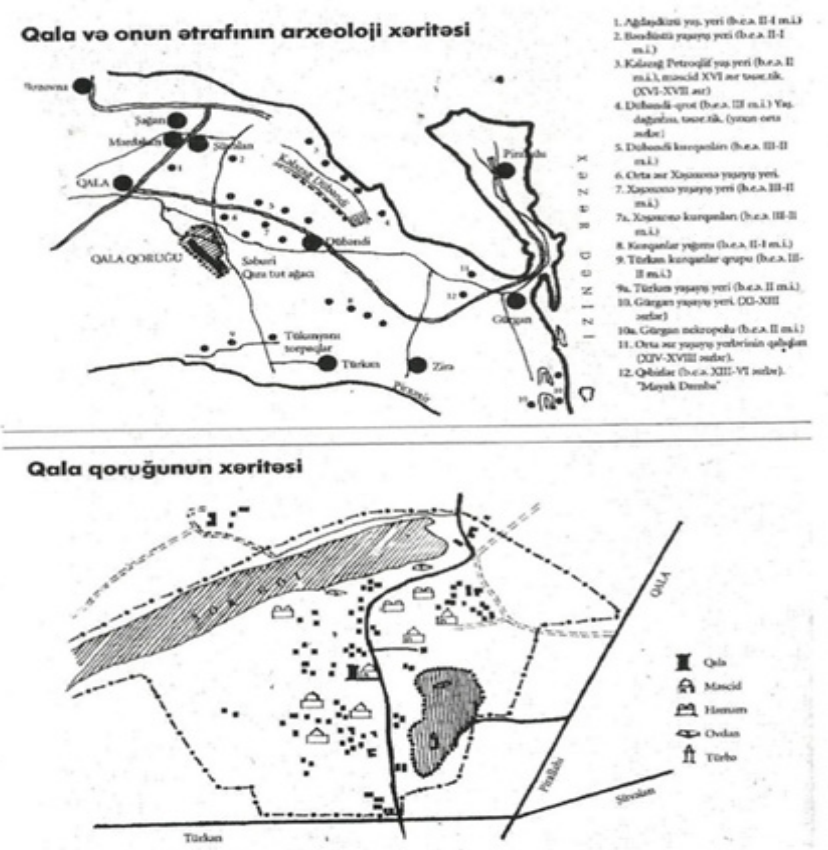

Çertyojlar arxeoloq İ.Đliyevin sxemlərinə osaslanır

Figure 5 Archeological ethnography mape of Qala.

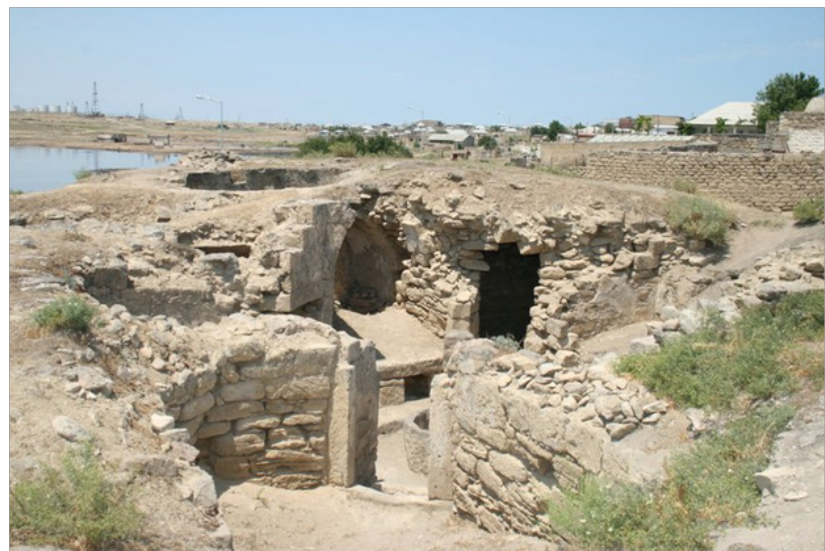

Figure 6 Historical Qum bath in archeological site.

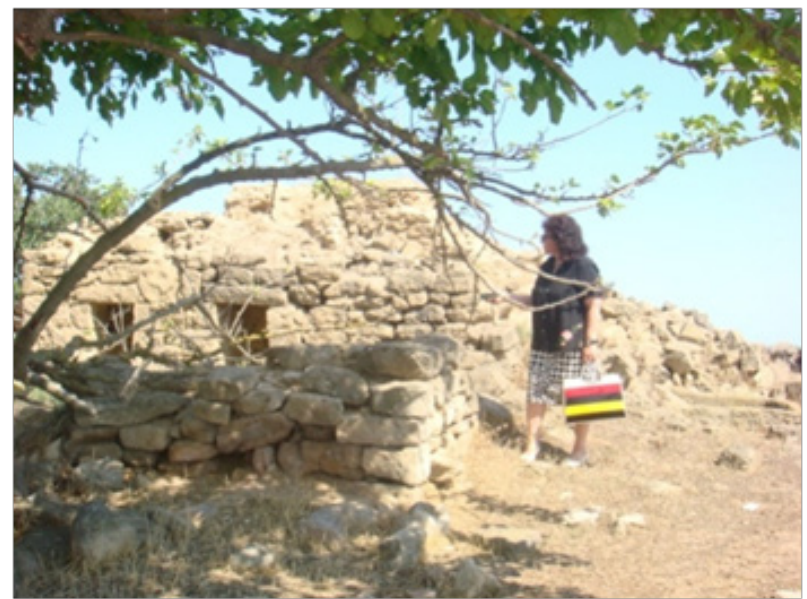

Figure 7 Archaeological excavations in the eastern part of the Nardaran Historical site and Cultural Reserve.

In 1998, in the southern part of the village, near the high school, in the area between constructed buildings, an ancient place was discovered(no archaeological excavation have been performed in this village, yet). Old dimension of this ancient residential place was about $300 \mathrm{Km}$. the north of this area was protected by a stone wall. Because of the constructions, the southern part of the building was corrupted and the upper layers were destroyed. In the buildings with stone foundation some old ceramic pieces were found. The remained traces were related to the Bronze era. It means that this place has a 4000 year history. Also, some residential places were found in the Aghdash, Khoshkhona, Dobandi. These findings are conducted by A. Aliove and can answer the questions about history of the Qale village, certainly.

Based on the information of a local old person, Haji Baba, a small pool with 5 meters depth and 2 meters diameter was found during the excavations near a well called Leila Boulaghi. The pool was covered with the milk, hand, and hair of the goat. This information indicates that Qale village was placed in a lower level than current level and demonstrated that this village was a residential place in the ancient times. The second stage of cultural traces of Qale village is related to the $10^{\text {th }}-20^{\text {th }}$ centuries. This doesn't mean that this village didn't have 
the habitability during the first millennium. Archaeological, historical and anthropological findings show that this village was an important business center. Abshiroun had the important role in the convoy trades. The village was related to the Baku city and other Azerbaijan areas through Pir Allah seaport and had the Intensive trade relations. Transit trade of the salt, cotton, cereals, and animal products was performed in this place. This matter was demonstrated by the findings of the 72 treasures found in the protected area of the Qale village.

Historical and cultural protected area of the Nardaran: the reason that the Nardaran village can be related to the Bronze era, is related to a place called "QalaGah" in which remains of early humans in the caves. The old part of Nardaran, which called Uomod Qayasi,is placed in the gardens near the sea in the Qala Gag. This village is surrounded from two sides by the rocks. On the East side, the Bilge village and on the West side, the KordKhaneand Pishgah rivers are located. There were pictureson the Umod rock are similar to the picturespainted on the Qubostan rocks. Petrographs and high reliefs on the stones attracted the scientists' attention. Historical traces of the Umod Qayasi rock related to the third millennium $\mathrm{BC}$ in the Abshiroun peninsula have the significant archaeological importance. Sara Ashourbili, Historian, states that this area is the very old area in the Abshiroun.

Astrological signs on the rocks between Nardaran and Bilge show that before Islam, the Zoroastrianism was important in this area. This matter is observed in the naming of the Nardaran village. In 1991, during repairing a local mosque, an old gravestone was found. This gravestone was related to the first millennium BC.

Different pictures of the animals, writings, and rural tools have been carved on the stones. The interesting point is that the Astrological patterns and stars pictures have been carved on a flat stone on a high mass that has the cup shape. These patterns include Ursa Major, Pole star, and the Pleiades. In the north of the Nardaran, near the sea and in the 250 meters height, there is a stone with 1500 meter width that was used to perform the religious practice related to the Islamic period. In the present, there was cultural- historical heritage that was attributed to the mediate centuries because the village was covered by the sand several times. Movement of the winds of the Caspian Sea and then shifting the sand levels caused some part of the village to be covered by the sand or revealed again later on. This changed the village history. A local researcher, E. Azimove, in his book entitled "Nardaran and its old history" states that there are 3-5 sand hills in the village. Initially, the city developed toward the East of the village, but because of covering that part of the village by sand, the new development of the village continued toward the western part. However, since the sand hills are moving from the east part toward the southwest area,some residential places have been constructed in the Eastern area of the village. In the lands excavated by the local people, an old structure was found that was covered by a sand layer. In the present, the remains of an old building, walls, and objects have been discovered in the Eastern part of the village. During our research in this place, we discovered these remainders. This indicates the importance and necessity of the archaeological excavations in the old area of the Nardaran and can reveal the cultural- historical heritage of this area (Figure 7)(Figure 8).

Cultural- historical protected area of the Atashgah (fire temple): by excavations performed in the fire-worshipping temple of the
Sourkhane, the historical-cultural value of these traces became doubly remarkable. The Atashgah temple was related to the $18^{\text {th }}$ century. During carving it was found that the Atashgah was constructed on an older temple. During this research, some buildings related to the $18^{\text {th }}$ century including several gas wells, ovens, and Places of animal sacrifice were found. Pottery pieces and Dukatin coins minted in 1841 were amogs to ther findings. Gas channel found in this area was interesting. There were mud covered gas channels in all the rooms of the temple.

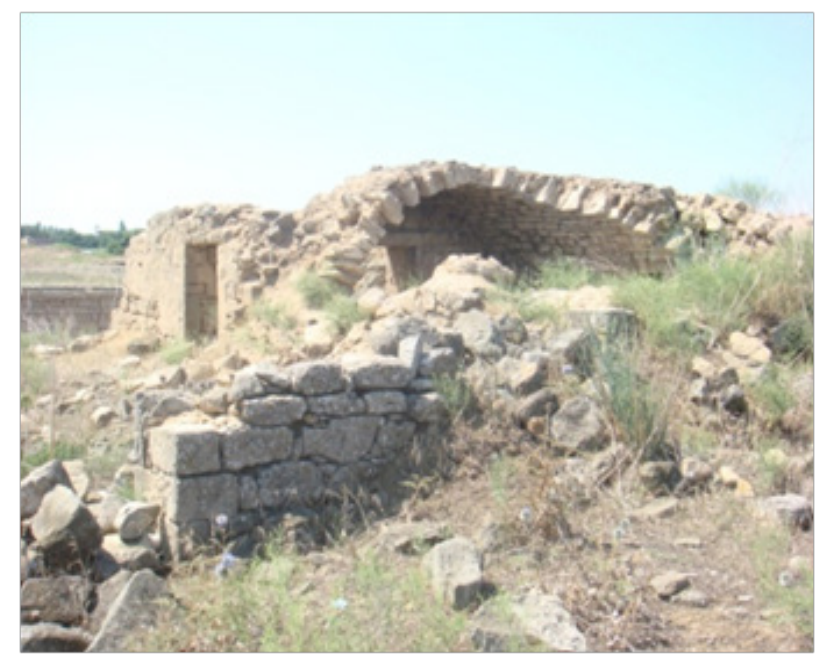

Figure 8 Archaeological excavations in the eastern part of the Nardaran Historical site and Cultural Reserve.

By archaeological excavations, it has been demonstrated that the fire worshipers used the natural gas for lighting and heating. This system was continued until the end of the $19^{\text {th }}$ century in the Sourkhane. Today, it is clearly known that the construction of temple depended on the Gas. The old temple constructed in the west of the present temple by the Indian fire worshipers in the early eighteenth century (Figure 9)(Figure 10). It is supposed that because of the geographical conditions of the Abshiroun and Geological factors, the whole Abshiroun peninsula and Baku have been habitable from 20000 years ago. Human settlement found in the new Sourkhane and Nardaran villages demonstrate this matter. Generally, there are Krougan and tombs related to the Bronze era and early of the Iron era in this peninsula. Also, some reliefs Carved on the stone and Anthropology figures related to the ancient era were found in the cemetery. The human settlements were found in the Darband, Turkan, Khoshkhane, Mardakan, Sholan, Betgidi and Amirjan villages and Pir Allah Islan and Ziglake (the first and third millennium BC). All these show that Abshiroun peninsula has had the human life conditionsfrom ancient era and could attract people. But, the strategic situation of this peninsula has attracted the attention of many occupiers. The archaeological results show that although the Abshiroun has been a human settlement place along the history, but the archaeological excavations are not sufficient in this historical protected area. In order to attract tourists and develop this area and obey the presidential decree, the archaeological research about the history, discovery of the cultural materials, as well as creating the cultural groups sems really necessary. 


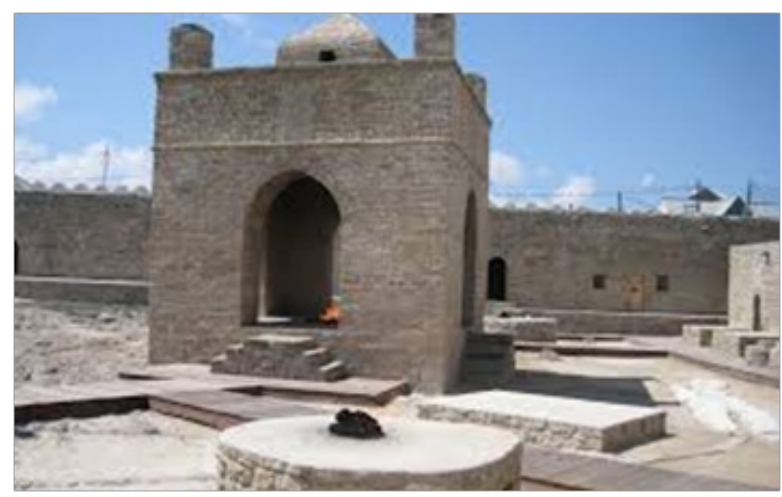

Figure 9 Atashgahthe State Historical-Architectural conservation site.

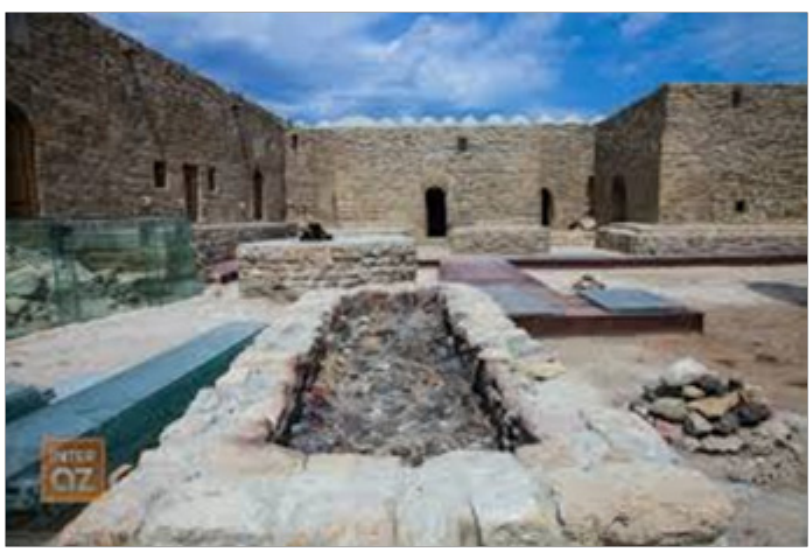

Figure 10 Atashgahthe State Historical-Architectural conservation site.

\section{Conclusion}

Geographical and archaeological research performed in the Abshiroun shows that there has been human settlement in this Abshiroun and Baku from 20000 years ago. Some residential places have been discovered near the Sourkhane and Nardaran villages. Generally, the ancient residential settlements related to the early era and Bronze era, stone engravings, and pictures painted on the stone with anthropological figures have been found in the ancient Qubostan and in throughout the whole peninsula. Duband, Turkan, Kharshkhoune, Mardakan, Sholan village, Pir Allah peninsula, Ziq lake, Binigdil, and Amirjan are some human settlements that have been discovered ( during the first and third millennium BC). These show that the Abshiroun have had the normal life situations for human settlements. But, the Geo- strategic situation of this peninsula, has attracted the attention of many Invaders and occupiers. This caused the creation of different architectures in the different time periods. The archaeological research has shown that there had been life, religion, and other matters related to the human life in the second and third millennium BC and the Stage of political development started early in the second millennium BC. The civil and political development of the Caucasus occurred in the same period and the archaeological collections of Caucasus civilization have been discovered. All this information has been obtained with the help of clay elements and different sets related to the second and third millennium BC and related to the Caucasus and Middle East civilization in the different areas of the Abshiroun. The archaeological investigations in the historical and protected area of the Abshiroun are not sufficient. The archaeological and architectural investigations in the protected areas of the Nardaran, Qala, and old city can offer more information about the archaeological heritage of this area. According to the Presidential Decree, Ilham Aliyev, the historical research should be developed to reveal the civil traces and the cultural research should provide the special goals in this field. ${ }^{9}$

\section{Acknowledgments}

None.

\section{Conflicts of interest}

Author declares that there is no conflicts of interest.

\section{References}

1. Aliyev I. Unknown Absheron. Baku; 2011.

2. Aliyeva R. Unique Gala village. Baku; 2007.

3. Azimbayov I. Ancient history of Nardaran. Baku; 1925.

4. History of Azerbaijan. Baku; 2007.

5. Guliyeva V. Khanaka in Baku fortress. İRS. Baku; 2011.

6. Farhad Ibrahimov. Kamil Farhadoghlu. Baku; 2002.

7. ASE. Baku; 1979.

8. Guliyeva V. Khanaka in Baku fortress. İRS. Baku; 2011.

9. Ibrahimov K. Archaelogical study history of Baku. Science and Life. Baku; 2010. 